\title{
Periodontal-Systemic Disease Education in United States Dental Hygiene Programs
}

\author{
Rebecca S. Wilder, B.S.D.H., M.S.; Katherine M. Thomas, B.S.D.H., M.S.; \\ Heather Jared, B.S.D.H., M.S.
}

Abstract: The relationship between periodontal disease and systemic disease has gained much attention in recent years in the dental profession and from national health care agencies. Two third-party providers are now modifying their dental reimbursements for patients who have periodontal disease and are pregnant or have cardiovascular disease. However, there are few reports in the dental or dental hygiene literature about how students are taught this information and how it is incorporated into the didactic and clinical aspects of the curriculum. A thirty-item survey and cover letter on these subjects were emailed to the directors of the 286 accredited dental hygiene programs in the United States in 2007. The response rate was 63 percent. According to these responses, the three most emphasized topics regarding oral-systemic disease are diabetes, tobacco use, and cardiovascular disease. Most programs (90 percent) use journal articles for instructional content, and 87 percent use the American Academy of Periodontology website for reference. Only 4 percent have content taught jointly with nursing, medical, or allied health students. The majority of directors ( 87 percent) indicated they could use more evidence-based educational materials to help teach the concepts to students. Only 9 percent of survey respondents thought that nurses and physicians are knowledgeable about the relationship of oral health to systemic disease. The findings indicate that dental hygiene program directors are confident about the education on oral-systemic content provided to their dental hygiene students, but would like additional evidence-based materials to help their students learn this topic.

Prof. Wilder is Associate Professor and Director of Graduate Dental Hygiene Education, University of North Carolina at Chapel Hill School of Dentistry; Ms. Thomas was a Master of Science degree candidate in dental hygiene education at the University of North Carolina at Chapel Hill School of Dentistry at the time of this study; and Prof. Jared is Research Associate Professor, Center for Oral Systemic Disease, University of North Carolina at Chapel Hill School of Dentistry. Direct correspondence and requests for reprints to Prof. Rebecca S. Wilder, Director of Graduate Dental Hygiene Education, University of North Carolina at Chapel Hill School of Dentistry, CB \#7450, Room 3280 Old Dental Bldg., Chapel Hill, NC 27599-7450; 919-966-8221 phone; 919-966-6761 fax; Rebecca_wilder@dentistry.unc.edu.

Key words: dental hygiene education, periodontitis, oral-systemic, dental hygiene curricula, interdisciplinary education

Submitted for publication 12/17/07; accepted 3/25/08

$\mathrm{N}$ ew science has emerged in recent years linking oral disease to systemic conditions. This link has produced a massive commentary throughout the health professions literature about potential periodontal-systemic connections and the associated implications for patient care in dentistry, medicine, nursing, pharmacy, and the allied health professions. Third-party providers such as Aetna and Cigna have modified their dental reimbursements for patients who have periodontal disease and are pregnant or have cardiovascular disease. ${ }^{1}$ For purposes of this article, the term "periodontal-systemic disease connection" will be used as it relates to the influence of periodontal conditions on systemic disease and the reverse: the influence of systemic disease on the periodontal condition.

Several periodontal-systemic disease connections have been investigated and reported in the peer-reviewed literature. Systemic conditions that have been studied and associated with periodontal disease include cardiovascular disease, ${ }^{2-5}$ diabetes mellitus, ${ }^{6-8}$ respiratory disease, ${ }^{9}$ adverse pregnancy outcomes, ${ }^{10-12}$ obesity, ${ }^{13}$ and stroke. ${ }^{14}$ Other risk factors found to exacerbate periodontal disease are tobacco use ${ }^{15}$ and positive genetic factors..$^{16}$ Although the science is not conclusive about all relationships between periodontal disease and systemic health, it is imperative that dental hygienists are knowledgeable about periodontal-systemic disease connections and potential risk factors as they relate to patient assessment, diagnosis, and care planning.

However, knowledge about risk for disease does not always translate into integration of the knowledge into practice. One example of a risk factor for oral-systemic disease that has a high level of evidence for an association is tobacco use. ${ }^{17}$ Fried and Rubinstein-DeVore surveyed dental hygiene program directors in the late 1980s and reported that dental hygiene students received limited tobacco use cessation education and that dental hygiene programs had no immediate plans for curriculum change. ${ }^{18}$ More recently, Davis et al. reported that their study of Indiana dental hygiene programs found that most faculty felt only moderately confident delivering 
tobacco education. ${ }^{19}$ They suggested the need for a comprehensive, competency-based tobacco curriculum to enhance and expand existing dental hygiene programs. In 2005, Ashe et al. reported on a study of 4,000 practicing North Carolina dental hygienists. ${ }^{20} \mathrm{~A}$ majority in this study agreed or strongly agreed that dental hygienists should be trained to provide tobacco cessation education to their patients. However, few felt adequately trained to provide such education.

Little has been published about curricula offerings in dental hygiene programs regarding other topics related to oral-systemic disease. Based on a review of the available literature, we do not know the extent to which dental hygiene students learn about potential systemic effects of periodontal disease and if they learn how to access information, determine a care plan for the patient, and refer to a dental or medical specialist when indicated. We also do not know if dental hygiene students have opportunities to practice strategies for communicating with patients and other health care providers about periodontalsystemic disease connections.

The American Dental Education Association (ADEA) has established basic core competencies for dental and dental hygiene education. The most recent ADEA Policy Statements ${ }^{21}$ emphasize that dental and dental hygiene programs should include curriculum content to teach students to work within an integrated health system. These statements also stress the need for academic institutions to teach the value of research and demonstrate the utility of scientific concepts in the curriculum so that students will appreciate the importance of incorporating these principles into practice. It is the responsibility of dental hygiene educators to prepare students for new and emerging responsibilities in health care. ${ }^{21}$ Nevertheless, little has been reported in the literature about the education regarding periodontal-systemic disease connections in dental hygiene curricula although this subject impacts several of the areas listed in the ADEA Policy Statements as well as the Competencies for Entry into the Profession of Dental Hygiene as approved by the ADEA House of Delegates in 2003.22 (See Figure 1.)

To address this knowledge gap, our study was conducted to 1) determine what topics are included in the didactic and clinical curricula of dental hygiene programs that address periodontal disease and systemic disease; 2) evaluate the extent to which periodontal oral-systemic disease content is taught in an interdisciplinary format with dental hygiene and other types of health professions students; 3) ascertain the opinions of dental hygiene program directors about the level of education their students receive pertaining to the relationship of periodontal disease and systemic disease; 4) elicit program directors' opinions about the knowledge level of other health professions faculty in their institution and in the community concerning the relationship of oral health to systemic disease; and 5) identify resources needed to teach this content.

\section{Methods}

A thirty-question survey was designed and divided into five sections: demographics, topics included in the didactic curriculum, topics included in the clinical curriculum, opinions, and resource materials. The survey contained Likert-scale questions along with open-ended and closed-ended questions. The survey was developed with the assistance of experts in the field of survey design as well as content experts on periodontal oral-systemic disease connections. Once designed, the survey instrument was approved by the Institutional Review Board (IRB) of the University of North Carolina at Chapel Hill and pilot-tested with the assistance of five dental hygiene program directors/faculty members from different institutional settings. Minor corrections were made and resubmitted to the IRB for final approval. The survey was posted on Survey Monkey, an online survey website engine, which provided a Uniform Resource Locator (URL) for the survey.

Program websites along with telephone calls were utilized to locate email addresses for the program directors. The survey instrument URL and cover letter explaining the purpose of the survey were emailed to the directors of the 286 accredited dental hygiene programs in 2007 . Ten declined to complete the survey, leaving a total of 276 potential responses. Two additional emails with the URL to the survey were sent three weeks apart to each program director, requesting his or her participation. Program directors were informed that their participation was voluntary with no incentives other than contributing to the dental hygiene literature.

The data were analyzed using descriptive statistical methods. The open-ended questions were separated into categories based on how participants responded. 


\section{ADEA Policy Statements}

\section{Education: Curriculum Content}

All dental education institutions and programs should: ...

Develop and support new models of oral health care that involve other health professionals as team members in assessing the oral health status of patients and teach dental students to assume leadership roles in the detection, early recognition, and management of a broad range of complex oral and general diseases and conditions. When possible, interdisciplinary educational opportunities should be pursued. ...

Provide experiences working as a member of an interdisciplinary health care team.

...

\section{Research}

... Dental educators should be expected to include new information and research findings in their courses of instruction and to encourage students to engage in critical thinking and research. Students should be encouraged to contribute to the development of new knowledge for the profession.

...

\section{Health Promotion and Disease Prevention}

...

ADEA supports and encourages research into the correlation between oral and general health, including the possible link between periodontal disease and heart and lung diseases, stroke, diabetes, low birth rates, and premature births.

ADEA supports and encourages the education of students, professionals, and the public on behaviors that will prevent disease and promote health, including preventive oral health care measures, proper nutrition, and tobacco cessation.

\section{Competencies for Entry into the Profession of Dental Hygiene}

\section{Patient/Client Care}

... Collaborate with the patient/client, and/or other health professionals, to formulate a comprehensive dental hygiene care plan that is patient/client-centered and based on current scientific evidence.

This competency includes:

a. Prioritize the care plan based on the health status and the actual and potential problems of the individual to facilitate optimal oral health.

b. Establish a planned sequence of care (educational, clinical, and evaluation) based on the dental hygiene diagnosis; identified oral conditions; potential problems; etiologic and risk factors; and available treatment modalities.

c. Establish a collaborative relationship with the patient/client in the planned care to include etiology, prognosis, and treatment alternatives.

d. Make referrals to other health care professionals.

Source: Competencies for entry into the profession of dental hygiene (as approved by the 2003 House of Delegates). J Dent Educ 2007;71(7):930-1. that emphasize content/experiences in periodontal-systemic disease connections

\section{Results}

A total of 173 program directors responded to the online survey, achieving a response rate of 63 percent. The majority of respondents were from technical/vocational institutes or community/junior colleges (61 percent, $n=105)$, followed by colleges or universities without a dental school (21 percent, $n=35)$. Seventeen percent $(n=28)$ were from colleges or universities with a dental school. The remaining programs represented the "other" category (.02 percent, $n=5$ ). The majority of programs (76 per- 
cent) employ between one and five full-time faculty members. Nineteen percent of the respondents were in the position of a faculty member but not the chair or director of the program. Primary response patterns are discussed below. Not all questions were answered by every respondent.

\section{Topics Included in the Didactic Curriculum}

Participants were asked to estimate the number of hours used to teach content on periodontal-systemic disease connections. Topics listed were adverse pregnancy outcomes, aging, cardiovascular disease (CVD), diabetes, HIV, obesity, osteoporosis, respiratory disease, stress, stroke, and tobacco use (Table 1). Most respondents indicated they use between one and two hours to teach the topics as they relate to periodontal disease. However, more didactic time is allotted for instruction on diabetes, tobacco use, and CVD. Forty-four percent lecture between three and five hours on tobacco use and diabetes, while 33 percent lecture six or more hours on tobacco use and 25 percent teach for six or more hours about diabetes. Twenty-two percent reported using six hours or more to teach content related to periodontal disease and CVD. When asked which three topics are emphasized the most in their curriculum, respondents answered diabetes ( 89 percent), tobacco use ( 77 percent), and CVD (72 percent).

A list of twenty courses was provided for participants to select where content is taught regarding oralsystemic disease as it relates to periodontal disease. The majority teach this content in periodontology (95.5 percent) followed by the second-year clinical course ( 85 percent), first-year clinical course (79 percent), dental hygiene theory course (72 percent), and general and oral pathology (72 percent).

Table 1. Topics and hours included in the didactic curriculum on oral-systemic disease, by percentage of total respondents and number of respondents

\begin{tabular}{|c|c|c|c|c|c|c|}
\hline Answer Options & 0 & $1-2$ & $3-5$ & $6-7$ & $>7$ & $\begin{array}{l}\text { Response } \\
\text { Totals }\end{array}$ \\
\hline $\begin{array}{l}\text { Adverse pregnancy outcomes } \\
\text { (low birthweight/preterm delivery) }\end{array}$ & $\begin{array}{l}0.7 \% \\
(1)\end{array}$ & $\begin{array}{l}78.7 \% \\
(107)\end{array}$ & $\begin{array}{l}16.9 \% \\
(23)\end{array}$ & $\begin{array}{l}2.9 \% \\
(4)\end{array}$ & $\begin{array}{l}0.7 \% \\
(1)\end{array}$ & 136 \\
\hline Aging & $\begin{array}{c}2.2 \% \\
(3)\end{array}$ & $\begin{array}{c}47.0 \% \\
(63)\end{array}$ & $\begin{array}{l}32.1 \% \\
(43)\end{array}$ & $\begin{array}{l}10.4 \% \\
(14)\end{array}$ & $\begin{array}{l}8.2 \% \\
(11)\end{array}$ & 134 \\
\hline Cardiovascular disease & $\begin{array}{l}0.0 \% \\
(0)\end{array}$ & $\begin{array}{l}41.3 \% \\
(57)\end{array}$ & $\begin{array}{l}36.2 \% \\
(50)\end{array}$ & $\begin{array}{l}13.8 \% \\
(19)\end{array}$ & $\begin{array}{l}8.7 \% \\
(12)\end{array}$ & 138 \\
\hline Diabetes & $\begin{array}{l}0.7 \% \\
(1)\end{array}$ & $\begin{array}{l}30.1 \% \\
(41)\end{array}$ & $\begin{array}{l}44.1 \% \\
(60)\end{array}$ & $\begin{array}{l}16.2 \% \\
(22)\end{array}$ & $\begin{array}{c}8.8 \% \\
(12)\end{array}$ & 136 \\
\hline Genetics & $\begin{array}{l}6.0 \% \\
(8)\end{array}$ & $\begin{array}{c}75.4 \% \\
(101)\end{array}$ & $\begin{array}{l}14.2 \% \\
(19)\end{array}$ & $\begin{array}{l}3.7 \% \\
(5)\end{array}$ & $\begin{array}{l}0.7 \% \\
(1)\end{array}$ & 134 \\
\hline HIV & $\begin{array}{l}0.7 \% \\
(1)\end{array}$ & $\begin{array}{l}50.4 \% \\
(68)\end{array}$ & $\begin{array}{l}37.0 \% \\
(50)\end{array}$ & $\begin{array}{l}6.7 \% \\
(9)\end{array}$ & $\begin{array}{l}5.2 \% \\
(7)\end{array}$ & 135 \\
\hline Obesity & $\begin{array}{c}17.2 \% \\
(23)\end{array}$ & $\begin{array}{c}70.9 \% \\
(95)\end{array}$ & $\begin{array}{c}8.2 \% \\
(11)\end{array}$ & $\begin{array}{c}2.2 \% \\
(3)\end{array}$ & $\begin{array}{c}1.5 \% \\
(2)\end{array}$ & 134 \\
\hline Osteoporosis & $\begin{array}{l}5.9 \% \\
(8)\end{array}$ & $\begin{array}{l}70.4 \% \\
(95)\end{array}$ & $\begin{array}{l}17.8 \% \\
(24)\end{array}$ & $\begin{array}{l}3.7 \% \\
(5)\end{array}$ & $\begin{array}{c}2.2 \% \\
(3)\end{array}$ & 135 \\
\hline Respiratory disease & $\begin{array}{l}3.0 \% \\
(4)\end{array}$ & $\begin{array}{l}67.2 \% \\
(90)\end{array}$ & $\begin{array}{l}21.6 \% \\
(29)\end{array}$ & $\begin{array}{l}5.2 \% \\
(7)\end{array}$ & $\begin{array}{l}3.0 \% \\
(4)\end{array}$ & 134 \\
\hline Stress & $\begin{array}{c}3.0 \% \\
(4)\end{array}$ & $\begin{array}{l}73.9 \% \\
(99)\end{array}$ & $\begin{array}{l}17.9 \% \\
(24)\end{array}$ & $\begin{array}{c}3.0 \% \\
(4)\end{array}$ & $\begin{array}{l}2.2 \% \\
(3)\end{array}$ & 134 \\
\hline Stroke & $\begin{array}{c}3.0 \% \\
(4)\end{array}$ & $\begin{array}{l}67.9 \% \\
(91)\end{array}$ & $\begin{array}{l}22.4 \% \\
(30)\end{array}$ & $\begin{array}{c}4.5 \% \\
(6)\end{array}$ & $\begin{array}{c}2.2 \% \\
(3)\end{array}$ & 134 \\
\hline Tobacco use & $\begin{array}{l}0.0 \% \\
(0)\end{array}$ & $\begin{array}{l}23.0 \% \\
(31)\end{array}$ & $\begin{array}{l}44.4 \% \\
(60)\end{array}$ & $\begin{array}{c}19.3 \% \\
(26)\end{array}$ & $\begin{array}{l}13.3 \% \\
(18)\end{array}$ & 135 \\
\hline \multicolumn{6}{|c|}{$\begin{array}{r}\text { Answered question } \\
\text { Skipped question }\end{array}$} & $\begin{array}{r}138 \\
36\end{array}$ \\
\hline
\end{tabular}


Reference materials used to teach about oral systemic disease as it relates to periodontal disease are listed in Table 2. Specific materials listed by participants were websites and content from the Cochrane Collaboration, National Institute for Dental and Craniofacial Research (NIDCR), National Institutes of Health (NIH), Colgate Oral Pharmaceuticals, Procter \& Gamble, and the American Academy of Periodontology (AAP). Table 3 lists journals and other publications used to teach about periodontal-systemic disease connections. Other publications cited by respondents in the "other" category were the Journal of the American Dental Association, Grand Rounds, Circulation, American Medical Journal, and Journal of Contemporary Dental Practice. Others responded that they use any dental-related journal that contains articles on the content. When asked which websites they use (if any) for this content, respondents listed the AAP (87 percent), the American Dental Hygienists' Association (ADHA) (59 percent), and the NIH (52 percent). Less than 16 percent use corporate or company websites for content resources (Table 4).

Only 4 percent of respondents indicated that they teach periodontal oral-systemic content to interdisciplinary student groups. Where interdisciplinary teaching occurred, it involved combining dental hygiene with nursing or other allied health students. Two respondents reported that their dental hygiene students conducted a project or patient education in the area of periodontal oral-systemic connections in conjunction with other health professions students. One of these interdisciplinary projects consisted of nursing students' providing a physical assessment and dental hygiene students' providing an oral assessment at a geriatric care center. The care plans are merged and presented to staff employees at the center. The other respondent reported that the program's dental hygiene students collaborated with other allied health students to provide a group patient education presentation that was related to periodontal systemic disease connections.

Eighty percent of respondents indicated that they provide formal training for their students in how to discuss or communicate aspects of periodontalsystemic disease connections with patients. The four methods most frequently reported were 1) communication techniques incorporated into all dental hygiene

Table 2. Reference materials used to teach about periodontal-systemic disease connections, by percentage and number of respondents

\begin{tabular}{lcc} 
& Percent & $\mathrm{N}$ \\
\hline Journal articles & $90 \%$ & 125 \\
Dental hygiene textbooks & $87 \%$ & 121 \\
Internet sites from national health care agencies & $58 \%$ & 80 \\
Internet sites from corporate manufacturers & $31 \%$ & 43 \\
Dental textbooks & $28 \%$ & 39 \\
Corporate print materials & $13 \%$ & 18 \\
Medical/nursing textbooks & $6 \%$ & 8 \\
Other & $8 \%$ & 11 \\
\end{tabular}

Table 3. Journals and other publications used to teach about periodontalsystemic disease connections, by percentage and number of respondents

\begin{tabular}{lcc} 
& Percent & $\mathrm{N}$ \\
\hline Journal of Dental Hygiene & $87 \%$ & 121 \\
Journal of Periodontology & $84 \%$ & 117 \\
Dimensions of Dental Hygiene & $64 \%$ & 89 \\
Access Magazine & $51 \%$ & 71 \\
Journal of Dental Education & $34 \%$ & 47 \\
Journal of Evidence-Based Dental Practice & $21 \%$ & 29 \\
Corporate publications & $9 \%$ & 12 \\
Other & $17 \%$ & 24
\end{tabular}

Table 4. Websites used to teach about periodontal-systemic disease connections, by percentage and number of respondents

\begin{tabular}{lrr} 
& Percent & $\mathrm{N}$ \\
\hline American Academy of Periodontology & $87.3 \%$ & 117 \\
American Dental Hygienists' Association & $59.0 \%$ & 79 \\
National Institutes of Health & $52.2 \%$ & 70 \\
Cochrane Library & $22.4 \%$ & 30 \\
Corporate/company website(s) & $15.7 \%$ & 21 \\
University website(s) & $8.2 \%$ & 11 \\
All of the above & $4.5 \%$ & 6 \\
None of the above & $2.2 \%$ & 3 \\
Other & $17.2 \%$ & 23 \\
\hline
\end{tabular}


theory courses; 2) case-based roleplays utilized to emphasize patient discussions about disease; 3) students instructed in how to communicate these aspects to clinical patients and evaluated on performance in clinic; and 4) communication strategies incorporated into presentations on patient treatment planning and oral hygiene.

\section{Topics Included in the Clinical Curriculum}

Participants provided information on how students are evaluated in the clinic on their ability to assess for periodontal-systemic disease connections, discuss those risks with the patient, and refer the patient to a specialist based on the risk factors
(Table 5). Of the 134 responses, the conditions most frequently evaluated regarding the student's ability to assess or perform a dental hygiene diagnosis or to discover a potential risk for systemic complications of periodontitis on the majority of their patients were the following: tobacco use (94 percent), diabetes (90 percent), CVD (87 percent), and adverse pregnancy outcomes (79 percent). Likewise, the students' ability to discuss risks with patients was evaluated mostly with tobacco use (92 percent), diabetes (92 percent), CVD (89 percent), and adverse pregnancy outcomes ( 85 percent). Participants were asked if their dental hygiene students are evaluated on their ability to refer the patient to a specialist based on the patient's risk factor(s) for periodontal-systemic disease connections. Fewer programs evaluate students on this

Table 5. Evaluation of DH students on their ability to assess, discuss, and refer patients who present with periodontalsystemic disease or risk factors for disease $(\mathrm{N}=134)$, by percentage of total respondents and number of respondents

Respondents were asked the following:

In your clinical curriculum, are students evaluated on their ability to:

- assess or perform a DH diagnosis to discover a potential risk for perio-systemic complications?

- discuss the risk with the patient?

- refer the patient to a specialist based on the patient's risk factor(s) for periodontal disease and systemic complications? Please place a mark in the appropriate box if they do the above on the majority of their patients.

\begin{tabular}{|c|c|c|c|c|}
\hline & $\begin{array}{l}\text { Assess/Perform } \\
\text { DH Diagnosis }\end{array}$ & Discuss the Risk & Refer to Specialist & Don't Know \\
\hline $\begin{array}{l}\text { Adverse pregnancy outcomes } \\
\text { (low birthweight/preterm delivery) }\end{array}$ & $\begin{array}{l}79 \% \\
(106)\end{array}$ & $\begin{array}{l}85 \% \\
(114)\end{array}$ & $\begin{array}{l}44 \% \\
(59)\end{array}$ & $\begin{array}{l}<1 \% \\
(5)\end{array}$ \\
\hline Aging & $\begin{array}{l}75 \% \\
(100)\end{array}$ & $\begin{array}{l}69 \% \\
(93)\end{array}$ & $\begin{array}{c}27 \% \\
(36)\end{array}$ & $\begin{array}{l}5 \% \\
(11)\end{array}$ \\
\hline Cardiovascular disease (CVD) & $\begin{array}{l}87 \% \\
(117)\end{array}$ & $\begin{array}{l}89 \% \\
(120)\end{array}$ & $\begin{array}{l}62 \% \\
(83)\end{array}$ & $\begin{array}{l}<1 \% \\
(2)\end{array}$ \\
\hline Diabetes & $\begin{array}{l}90 \% \\
(121)\end{array}$ & $\begin{array}{l}92 \% \\
(124)\end{array}$ & $\begin{array}{c}68 \% \\
(91)\end{array}$ & $\begin{array}{l}<1 \% \\
(2)\end{array}$ \\
\hline Genetics & $\begin{array}{c}48 \% \\
(56)\end{array}$ & $\begin{array}{l}42 \% \\
(57)\end{array}$ & $\begin{array}{l}19 \% \\
(26)\end{array}$ & $\begin{array}{c}21 \% \\
(28)\end{array}$ \\
\hline HIV & $\begin{array}{l}75 \% \\
(100)\end{array}$ & $\begin{array}{l}74 \% \\
(99)\end{array}$ & $\begin{array}{c}50 \% \\
(67)\end{array}$ & $\begin{array}{l}<1 \% \\
(8)\end{array}$ \\
\hline Obesity & $\begin{array}{l}51 \% \\
(68)\end{array}$ & $\begin{array}{c}46 \% \\
(62)\end{array}$ & $\begin{array}{l}19 \% \\
(26)\end{array}$ & $\begin{array}{l}16 \% \\
(22)\end{array}$ \\
\hline Osteoporosis & $\begin{array}{l}63 \% \\
(85)\end{array}$ & $\begin{array}{l}66 \% \\
(89)\end{array}$ & $\begin{array}{l}32 \% \\
(43)\end{array}$ & $\begin{array}{l}<1 \% \\
(13)\end{array}$ \\
\hline Respiratory disease & $\begin{array}{l}66 \% \\
(89)\end{array}$ & $\begin{array}{l}63 \% \\
(84)\end{array}$ & $\begin{array}{c}39 \% \\
(53)\end{array}$ & $\begin{array}{l}<1 \% \\
(11)\end{array}$ \\
\hline Stress & $\begin{array}{l}64 \% \\
(86)\end{array}$ & $\begin{array}{l}61 \% \\
(82)\end{array}$ & $\begin{array}{c}25 \% \\
(33)\end{array}$ & $\begin{array}{l}<1 \% \\
(13)\end{array}$ \\
\hline Stroke & $\begin{array}{l}75 \% \\
(101)\end{array}$ & $\begin{array}{l}75 \% \\
(100)\end{array}$ & $\begin{array}{c}39 \% \\
(53)\end{array}$ & $\begin{array}{c}<1 \% \\
(7)\end{array}$ \\
\hline Tobacco use & $\begin{array}{c}94 \% \\
(126)\end{array}$ & $\begin{array}{c}92 \% \\
(124)\end{array}$ & $\begin{array}{c}58 \% \\
(78)\end{array}$ & $\begin{array}{c}<1 \% \\
(3)\end{array}$ \\
\hline
\end{tabular}


aspect, but when the students are evaluated, the most frequently reported conditions that are referred are diabetes (68 percent), CVD (62 percent), and tobacco use ( 58 percent).

\section{Opinions}

One section of the survey focused on opinions of dental hygiene program directors regarding periodontal oral-systemic education, resource materials, and levels of expertise in their programs and community (Table 6). The respondents felt confident in their faculty members' knowledge level regarding oral-systemic content and also in their ability to evaluate critically the literature and determine levels of evidence. Only 28 percent strongly agreed or agreed that they needed more experts to teach the content. Virtually all respondents ( 99 percent) strongly agreed or agreed that their dental hygiene students were knowledgeable about the role of inflammation and its impact on oral-systemic complications. Ninetynine percent agreed or strongly agreed that dental hygienists will play an important role in the future in assessing patients' risk for systemic complications due to oral health status. In contrast, the respondents reported disagreement or strong disagreement when questioned about nurses' and physicians' knowledge of periodontal-systemic disease connections. Seventy percent disagreed or strongly disagreed that nurses and physicians in their geographic location are well educated about oral-systemic disease. Only 9 percent responded that nurses and physicians in general are knowledgeable about periodontal-systemic disease connections. The majority (87 percent) of respondents indicated they could use more evidence-based educational materials to teach dental hygiene students about oral-systemic disease.

Table 6. Opinions of dental hygiene program directors about periodontal-systemic disease education, resource materials, and levels of expertise in their programs and community, by percentage of total respondents

\begin{tabular}{|c|c|c|c|c|c|}
\hline & $\begin{array}{l}\text { Strongly } \\
\text { Agree }\end{array}$ & Agree & Disagree & $\begin{array}{l}\text { Strongly } \\
\text { Disagree }\end{array}$ & $\begin{array}{l}\text { Don't } \\
\text { Know }\end{array}$ \\
\hline $\begin{array}{l}\text { The clinical faculty in our program are knowledgeable } \\
\text { about periodontal-oral-systemic research. }\end{array}$ & $45.9 \%$ & $51.9 \%$ & $1.5 \%$ & $0.0 \%$ & $0.7 \%$ \\
\hline $\begin{array}{l}\text { The faculty who teach about the periodontal- } \\
\text { oral-systemic connection know how to critically } \\
\text { evaluate the literature and determine levels of evidence. }\end{array}$ & $64.2 \%$ & $33.6 \%$ & $0.7 \%$ & $0.0 \%$ & $1.5 \%$ \\
\hline $\begin{array}{l}\text { We need more experts at our school who can teach this } \\
\text { subject to our dental hygiene students. }\end{array}$ & $5.2 \%$ & $22.4 \%$ & $60.4 \%$ & $10.4 \%$ & $1.5 \%$ \\
\hline $\begin{array}{l}\text { Dental hygiene students should be taught how to } \\
\text { assess a patient's periodontal condition and advise him or } \\
\text { her about possible systemic complications. }\end{array}$ & $88.1 \%$ & $11.9 \%$ & $0.0 \%$ & $0.0 \%$ & $0.0 \%$ \\
\hline $\begin{array}{l}\text { Dental hygienists will play an important role in the } \\
\text { future in assessing patients' risk for systemic } \\
\text { complications due to oral health status. }\end{array}$ & $85.9 \%$ & $13.3 \%$ & $0.0 \%$ & $0.0 \%$ & $0.7 \%$ \\
\hline $\begin{array}{l}\text { Our dental hygiene students are knowledgeable } \\
\text { about the role of inflammation and its impact on } \\
\text { oral-systemic complications. }\end{array}$ & $57.0 \%$ & $42.2 \%$ & $0.7 \%$ & $0.0 \%$ & $0.0 \%$ \\
\hline $\begin{array}{l}\text { Our dental hygiene program does an excellent job of } \\
\text { teaching our dental hygiene students about the } \\
\text { periodontal-oral-systemic connection. }\end{array}$ & $39.3 \%$ & $55.6 \%$ & $4.4 \%$ & $0.0 \%$ & $0.7 \%$ \\
\hline $\begin{array}{l}\text { Our dental hygiene program could use more evidence- } \\
\text { based educational materials (slides, pamphlets, etc.) to } \\
\text { help teach these concepts to dental hygiene students. }\end{array}$ & $35.8 \%$ & $51.5 \%$ & $9.0 \%$ & $0.7 \%$ & $3.0 \%$ \\
\hline $\begin{array}{l}\text { Nurses and physicians in our geographic location are well } \\
\text { educated about the periodontal-oral-systemic connection. }\end{array}$ & $0.7 \%$ & $4.4 \%$ & $48.9 \%$ & $20.7 \%$ & $25.2 \%$ \\
\hline $\begin{array}{l}\text { Generally, nurses and physicians are knowledgeable about } \\
\text { oral health and its relationship to systemic disease. }\end{array}$ & $0.7 \%$ & $8.1 \%$ & $49.6 \%$ & $21.5 \%$ & $20.0 \%$ \\
\hline Our program needs to provide more content on the & $6.8 \%$ & $38.3 \%$ & $45.9 \%$ & $6.8 \%$ & $2.3 \%$ \\
\hline
\end{tabular}
health.

Note: Percentages may not total $100 \%$ because of rounding. 


\section{Resources}

The last section of the survey asked participants if their program supplies resource materials to patients on this subject and if they provide referral letters to patients if they are referred to a specialist regarding potential periodontal-systemic disease connections. Sixty-two percent said they supply resource materials, and 63 percent provide referral letters to patients. The final question asked if there was anything that they would like to have that would assist them in teaching this content to dental hygiene students. The top three resources were 1) patient pamphlets in both English and Spanish; 2) updated PowerPoint presentations, DVDs, and textbook information; and 3) extensive case studies with pictures (Figure 2).

\section{Discussion}

Overall, U.S. dental hygiene directors were very positive about the knowledge of their students and faculty regarding periodontal-systemic disease connections. In addition, program directors indicated that all of their faculty who teach this content to dental hygiene students are knowledgeable about how to critically evaluate the literature and determine levels of evidence. This is an improvement from a 2001 study by Chichester et al., who surveyed dental hygiene program directors regarding utilization of evidence-based (EB) teaching in U.S. dental hygiene curricula. ${ }^{23}$ At that time, 37 percent of respondents indicated that a major barrier to fully incorporating EB approaches in their dental hygiene program was lack of faculty skills.

The topics most emphasized in the didactic curriculum as they relate to periodontal-systemic disease connections are tobacco use, diabetes, and cardiovascular disease. Tobacco is a known risk factor for periodontal disease ${ }^{15}$ and is widely implicated in systemic complications such as oral cancer $^{24}$ and pulmonary disease. ${ }^{9}$

The findings indicate that dental hygiene programs evaluate their students' capacity to assess periodontal-systemic disease risks/complications and communicate with patients concerning these issues.

- Patient pamphlets (in English and Spanish) and other visuals for patients

- Updated PowerPoint presentations/textbooks/DVDs

- Extensive case-based studies (pictures would be beneficial)

- Information from other dental hygiene programs on how they handle patient referrals

- Videos/curricula geared toward the hygienist/interactive teaching modules, tests, and assessment tools

- $\quad$ Slides, movies, Internet programs, CDs, other media

- More researchers in the field who know how to teach and enjoy sharing with students

- Guest lecturer to do summary of periodontal-oral-systemic link

- CE for faculty

- Literature for patients

- Better access to information

- Evidence-based literature on how to present this topic with patients

- More evidence-based data for students

- Specific journal designed to update dental/medical professionals on this topic only

- Posters

- Sample letters of referral to specialists

- More online access to journals and PDF files for the students

- More time to cover these aspects

- Simulation exercises

- Material to simplify the topic to the students

- Learning strategies for teaching these topics

Figure 2. Supplies/resources desired by respondents to teach periodontal-systemic disease content to dental hygiene students 
Respondents indicated that 94 percent of students are evaluated on their ability to assess periodontalsystemic disease risks in patients and perform a dental hygiene diagnosis, and 92 percent are evaluated on their ability to discuss these risks with patients. However, only 58 percent of respondents reported that patients identified as being at risk are referred to a specialist. The survey instrument did not ask if tobacco cessation education is part of the discussion of risk or referral to a specialist. Other studies have reported a lack of tobacco cessation implementation in practice. ${ }^{20,25}$ However, dental hygienists are more likely to provide tobacco cessation counseling to patients with periodontal disease than other dental patients. ${ }^{26}$

Diabetes mellitus is a known risk factor for periodontal disease. ${ }^{27}$ Ninety percent of dental hygiene programs are evaluating students on their ability to perform a dental hygiene diagnosis related to diabetes; 92 percent evaluate whether students discuss diabetes-associated periodontal risks with the patient; and 68 percent evaluate students on their ability to refer to a specialist. Of all of the topics listed in the clinical curriculum, survey respondents reported that referrals for diabetes occurred the most frequently. This is encouraging as it indicates that many dental hygiene students are learning how to effect change in targeted population groups by identifying disease and providing preventive interventions.

Faculty who teach content relating periodontal disease to systemic disease use journal articles ( 90 percent), dental hygiene textbooks ( 87 percent), and Internet sites from national health care agencies (58 percent) for resource materials to teach this content. Faculty primarily use peer-reviewed research journals as information sources for instruction about periodontal-systemic disease connections. This is encouraging since a 2001 study found the majority of dental hygiene students used textbooks as the most widely used method of information retrieval. ${ }^{23}$ Since the 2001 study, students and faculty have many more resources easily available, including electronic access to most scientific journals and easy identification of topics through electronic search engines. Although textbooks are useful, the content may be out-of-date by publication date, given the extensive research related to periodontal-systemic disease connections in recent years. In addition, students need to be taught how to access current information, read and critique the scientific literature, and make patient decisions based on current evidence. It would be interesting to know if this ability to access evidence-based informa- tion in school carries over into a desire to do so once in clinical practice.

Nearly half of dental hygiene program directors indicated their program needs to provide more content on the relationship between periodontal disease and systemic health. Eighty-seven percent agreed or strongly agreed that they could use more evidence-based educational materials to help teach these concepts to dental hygiene students. Several indicated the need for patient pamphlets in English and Spanish and other visuals for patients. Others wanted extensive case studies to use with students. Other respondents indicated that they needed methods to locate available information. These responses suggest that dental hygiene curricular content in periodontal-systemic disease connections could be enhanced by easily accessible scientific, evidencebased educational materials, especially for newer dental hygiene program faculty who may not have the time, technology, or IT support to produce teaching materials.

A disturbing finding of the study was the lack of integration of content, both didactically and clinically, with other health care providers. Only six programs teach this content with nursing students or other allied health students. Of those six programs, only two require dental hygiene students to conduct a joint project or patient education in the area of oralsystemic disease. In 1995, the Institute of Medicine (IOM) report Dental Education at the Crossroads: Challenges and Change recommended that dentists be prepared for more medically based modes of oral health care and prepared to work with more medically compromised patients along with colleagues in medical schools and academic health centers. ${ }^{28} \mathrm{In}$ their article "Oral Health Care in the $21^{\text {st }}$ Century: Implications for Dental and Medical Education," Hendricson and Cohen contend that "the most pressing oral health issues are no longer purely dental in nature but fall into the overlapping educational and patient care environments of physicians, dentists, and other health care providers." ${ }^{29}$ In 2006, Rafter et al. referred to dental education as taking the "silo" approach that is commonly found in health education. ${ }^{30}$ Very little exists in the literature reporting initiatives involving collaborations with dental or dental hygiene education and other health care providers. This study supports the concept that, in general, dental hygiene education is isolated from other health professionals and promotes little integration with other health care providers. Since this study is representative of 63 percent of U.S. dental hygiene programs, there may 
be other programs that are incorporating periodontalsystemic disease content with other health care disciplines. In addition, other topic areas in the curriculum may be integrated. However, it is not clearly evident in the literature.

Only 5 percent of dental hygiene directors agreed or strongly agreed that nurses and physicians in their geographic location are well educated about periodontal-systemic disease connections, and 25 percent of directors answered that they did not know about the relevant knowledge of nurses and physicians in their geographic location. A recent study reported on the knowledge level and behaviors of obstetricians and gynecologists regarding periodontal disease and adverse pregnancy outcomes. ${ }^{31} \mathrm{~A}$ high number of obstetricians correctly associated periodontal disease with bacteria, yet erroneously believed that tooth decay, aging, and excess sugar were also associated with disease. The study also found that while there is some knowledge of periodontal disease as a potential risk factor for adverse pregnancy outcomes among obstetricians, there is limited incorporation of this knowledge into clinical practice. These data indicate that there is an opportunity for dental hygiene to take the lead in developing alliances with physicians, nurses, nurse practitioners, health educators, and others who can assist in assessing and referring patients who have risk factors for oral-systemic disease. If future predictions are correct and dental hygienists and other allied oral health care providers take on an expanded role in the assessment and diagnosis of treatment needs for patients, they will need to have current knowledge of the literature regarding periodontal-systemic disease connections and also have the skills to work with an interdisciplinary team. ${ }^{32}$

An investigation is currently under way to investigate periodontal-systemic disease content in dental school curricula in the United States and Canada. In addition, the authors are studying the knowledge, practice behaviors, and opinions of nurse practitioners, physician assistants, and certified nurse midwives related to periodontal-systemic disease connections. Dentistry and dental hygiene must work with other health care providers to promote oral health and to assess and diagnose patients and refer them to appropriate venues for care. Looking beyond our profession and collaborating with other providers are the best ways to expand oral health care out of the silo.

\section{Conclusions}

The findings from this survey indicate that dental hygiene directors are confident about the periodontal-systemic disease education of the dental hygiene students in their programs. However, they would like to have increased access to evidencebased materials for teaching concepts to students. In addition, most directors do not think that nurses and physicians are knowledgeable about oral health and its relationship to systemic disease. More research needs to be conducted to identify strategies that will assist the efforts of faculty to translate this area of science into dental and dental hygiene curricula as well as clinical practice.

\section{Acknowledgments}

This study was supported by a grant from Colgate Oral Pharmaceuticals.

\section{REFERENCES}

1. Kaiser Daily Health Policy Report, September 19, 2006. At: www.kaisernetwork.org/daily_reports/rep_index.cfm. Accessed: December 17, 2007.

2. Desvarieux M, Demmer RT, Rundek T, Boden-Albala B, Jacobs DR Jr, Sacco RL, et al. Periodontal microbiota and carotid intima-media thickness: the oral infections and vascular disease epidemiology study (INVEST). Circulation 2005;111(5):576-82.

3. Tiong AY, Brieger D. Inflammation and coronary artery disease. Am Heart J 2005;150:11-8.

4. Meurman JH, Sanz M, Janket SJ. Oral health, atherosclerosis, and cardiovascular disease. Crit Rev Oral Biol Med 2004;15:403-13.

5. Wu T, Trevisan M, Genco RJ, Dorn JP, Falkner KL, Sempos CT. Periodontal disease and risk of cerebrovascular disease: the first National Health and Nutrition Examination Survey and its follow-up study. Arch Intern Med 2000;160(18):2749-55.

6. Grossi SG, Skrepcinski FB, DeCaro T, Robertson DC, Ho AW, Dunford RG, et al. Treatment of periodontal disease in diabetics reduces glycated hemoglobin. J Periodontol 1997;68(8):713-9.

7. Grossi SG, Genco RJ. Periodontal disease and diabetes mellitus: a two-way relationship. Ann Periodontol 1998;3:51-61.

8. Taylor GW. Bidirectional interrelationships between diabetes and periodontal diseases: an epidemiologic perspective. Ann Periodontol 2001;6:99-112.

9. Scannapieco FA, Ho AW. Potential associations between chronic respiratory disease and periodontal disease: analysis of National Health and Nutrition Examination Survey III. J Periodontol 2001;72:50-6. 
10. Offenbacher S, Katz V, Fertik G, Collins J, Boyd D, Maynor $\mathrm{G}$, et al. Periodontal infection as a possible risk factor for preterm low birth weight. J Periodontol 1996;67(10 Suppl):1103-13.

11. Jeffcoat MK, Geurs NC, Reddy MS, Cliver SP, Goldenberg RL, Hauth JC. Periodontal infection and preterm birth: results of a prospective study. J Am Dent Assoc 2001;132:875-80.

12. Michalowicz BS, Hodges JS, DiAngelis AJ, Lupo VR, Novak MJ, Ferguson JE, et al. OPT Study. Treatment of periodontal disease and the risk of preterm birth. N Engl J Med 2006;355(18):1885-94.

13. Reeves AF, Rees JM, Schiff M, Hujoel P. Total body weight and waist circumference associated with chronic periodontitis among adolescents in the United States. Arch Pediatr Adolesc Med 2006;160:894-9.

14. Joshipura KJ, Hung HC, Rimm EB, Willett WC, Ascherio A. Periodontal disease, tooth loss, and incidence of ischemic stroke. Stroke 2003;34(1):47-52.

15. Tomar SL, Asma S. Smoking-attributable periodontitis in the United States: findings from NHANES III (National Health and Nutrition Examination Survey). J Periodontol 2000;71(5):743-51.

16. Brett PM, Zygogianni P, Griffiths GS, Tomaz M, Parkar M, D'Aiuto F, et al. Functional gene polymorphisms in aggressive and chronic periodontitis. J Dent Res 2005;84(12):1149-53.

17. Winn DM. Tobacco use and oral disease. J Dent Educ 2001;65(4):306-12.

18. Fried JL, Rubinstein-DeVore L. Tobacco use cessation curricula in the U.S. dental schools and dental hygiene programs. J Dent Educ 1990;54(12):730-5.

19. Davis JM, Stockdale MS, Cropper M. The need for tobacco education: studies of collegiate dental hygiene patients and faculty. J Dent Educ 2005;69(12):1340-52.

20. Ashe TE, Elter JR, Southerland JH, Strauss RP, Patton LL. North Carolina dental hygienists' assessment of patients' tobacco and alcohol use. J Dent Hygiene 2005;79(2):9. Available from Epub 2005 Apr 1.
21. ADEA policy statements. J Dent Educ 2007;71(7):91325.

22. Competencies for entry into the profession of dental hygiene (as approved by the 2003 House of Delegates). J Dent Educ 2007;71(7):929-33.

23. Chichester SR, Wilder RS, Mann GB, Neal E. Utilization of evidence-based teaching in U.S. dental hygiene curricula. J Dent Hygiene 2001;75(2):156-64.

24. Silverman S Jr. Demographics and occurrence of oral and pharyngeal cancers: the outcomes, the trends, the challenge. J Am Dent Assoc 2001;132(Suppl):7S-11S.

25 . Smith SS, Beckley T, Fiore MC. Health care provider use of guideline-based smoking cessation interventions: results from the 2003 Wisconsin tobacco survey. WMJ 2005;104(4):28-31.

26. Monson AL, Engeswick LM. Promotion of tobacco cessation through dental hygiene education: a pilot study. J Dent Educ 2005;69(8):901-11.

27. Mealey B, Oates TW. Diabetes mellitus and periodontal diseases. J Periodontol 2006;77:1289-303.

28. Field MJ, ed. Dental education at the crossroads: challenges and change. A report of the Institute of Medicine. Washington, DC: National Academy Press, 1995.

29. Hendricson WD, Cohen PA. Oral health care in the $21 \mathrm{st}$ century: implications for dental and medical education. Acad Med 2001;76(12):1181-206.

30. Rafter ME, Pesun IJ, Herren M, Linfante JC, Mina M, Wu $\mathrm{CD}$, Casada JP. A preliminary survey of interprofessional education. J Dent Educ 2006;70(4):417-27.

31. Wilder RS, Robinson C, Jared HL, Lieff SP, Boggess KM. Obstetricians' knowledge and practice behaviors concerning periodontal health and preterm delivery and low birth weight. J Dent Hygiene [Internet] 2007;81(4).

32. McKinnon M, Luke G, Bresch J, Moss M, Valachovic RW. Emerging allied dental workforce models: considerations for academic dental institutions. J Dent Educ 2007;71(11):1476-91. 